\title{
Effect of diphenylhydantoin on gamma aminobutyric acid (GABA) and succinate activity in rat Purkinje cells
}

\author{
EDWARD HITCHCOCK AND THEA GABRA-SANDERS \\ From the Department of Surgical Neurology, Western General Hospital, Edinburgh
}

SUMMARY A study has been made of the effect of diphenylhydantoin (DPH) upon the levels of gamma aminobutyric acid (GABA) and succinic dehydrogenase in rat Purkinje cells. DPH was administered over 26 days in chronic experiments using controls receiving the same injection vehicle without DPH. Animals in this group received daily $1.25 \mathrm{mg} / \mathrm{kg}$ body weight, $12.5 \mathrm{mg} / \mathrm{kg}$ body weight, and $50 \mathrm{mg} / \mathrm{kg}$ body weight DPH. Acute experiments were carried out over the course of not more than four days, three groups of animals receiving $75 \mathrm{mg} / \mathrm{kg}$ body weight, $87.5 \mathrm{mg} / \mathrm{kg}$ body weight, and $100 \mathrm{mg} / \mathrm{kg}$ body weight DPH. No effect upon succinic dehydrogenase could be demonstrated at any dose level. There was a significant progressive loss of GABA with increasing dosage of DPH.

Diphenylhydantoin (Epanutin) is probably the most widely used anticonvulsant and, as with other anticonvulsants, it has been suggested that its effect is due to either increasing the level of gamma aminobutyric acid (GABA) available, or possibly acting itself as a GABA-like substance (Meldrum, 1975). Saad et al. (1972) showed that diphenylhydantoin (DPH) increased cerebral hemisphere GABA content in mice.

The effect of chronic or toxic administration of DPH is less clearly defined. Neurotoxicity is manifested in man by cerebellar signs, and although these effects can occur with small concentrations of DPH (Kutt et al., 1964; Gordon, 1969; Logan and Freeman, 1969; Glaser, 1972), they usually occur when the serum level exceeds $30 \mu \mathrm{g} / \mathrm{ml}$, while in patients with neurotoxicity, seizure control may be lost (Levy and Fenichel, 1965). Sawaya et al. (1975), investigating the action of anticonvulsants related to GABA metabolism in whole brain homogenates, found that DPH apparently activated GABA-T but inhibited succinic semialdehyde dehydrogenase. Histochemical studies (Karkos, 1975) on rat cerebellum revealed no change in the histochemistry of cerebellar succinic after six months' administration of phenytoin, despite morphological changes in Purkinje and Golgi cells. No reports have appeared on the histochemical changes on GABA induced by chronic diphenylhydantoin administration. Numerous studies (Fahn

Address for reprint requests: Mr E. Hitchcock, Department of Surgical Neurology, Western General Hospital, Crewe Road, Edinburgh EH4 2XU, Scotland.

Accepted 17 December 1976 and Côté, 1968) show that GABA attains its highest level in the Purkinje cell layer, and that phenytoin is selectively accumulated in the cerebellum (Noach et al., 1958). The rat cerebellum, therefore, and the Purkinje layer in particular, was chosen as indicator of the effect of DPH on GABA, and at the same time investigation of succinate activity was made in the same structures.

\section{Material and methods}

In the present study we have investigated the GABA and succinic content of the cerebellum in chronic and acute experiments. In the chronic experiments DPH was administered over 26 days. Animals used as controls received injections without DPH, and were injected over the same period with $1 \mathrm{ml}$ of the vehicle (alcohol 10\%, glycol $40 \%$, distilled water $50 \%$ ). Test animals were injected daily intraperitoneally with $1 \mathrm{ml}$ diphenylhydantoin dissolved in the vehicle to give final concentrations of $0.25 \mathrm{mg} / \mathrm{ml}$, $2.5 \mathrm{mg} / \mathrm{ml}$, and $10 \mathrm{mg} / \mathrm{ml}$. Adult female Chester Beattie rats with average weight $200 \mathrm{~g} \pm 1 \mathrm{~g}$ were used for both test and control groups. Group 1 received $1.25 \mathrm{mg} / \mathrm{kg}$ body weight, group $212.5 \mathrm{mg} / \mathrm{kg}$ body weight, and group $350 \mathrm{mg} / \mathrm{kg}$ body weight. The intraperitoneal route was chosen to ensure absorption rather than oral administration as other investigators have done.

The acute experiments were performed with toxic doses of DPH again administered intraperitoneally. These were given in three doses: $15 \mathrm{mg} / \mathrm{ml}(75 \mathrm{mg} / \mathrm{kg}$ 
body weight), $17.5 \mathrm{mg} / \mathrm{ml}$ ( $87.5 \mathrm{mg} / \mathrm{kg}$ body weight), and $20 \mathrm{mg} / \mathrm{ml}(100 \mathrm{mg} / \mathrm{kg}$ body weight). All these injections rapidly induced marked toxic changes with failure of the animals to eat, paucity of movement, and, in high doses, gross ataxia. Animals in the first group $(75 \mathrm{mg} / \mathrm{kg}$ ) were sacrificed after four days because they looked ill although without obvious ataxia. The second group $(87.5 \mathrm{mg} / \mathrm{kg}$ ) was sacrificed after three days because of illness, and although there was no obvious ataxia the animals had a gross paucity of movement and generalised weakness. The group receiving the highest dose $(100 \mathrm{mg} / \mathrm{kg})$ was sacrificed after two days because of ill health and obvious ataxia.

At the end of the period of administration, all animals were anaesthetised with urethane $20 \%$ ( $6 \mathrm{ml} / \mathrm{kg}$ body weight), and the whole cerebellum and brain stem were removed in vivo. The cerebellum was immediately mounted on a cryostat stub and rapidly frozen using liquid $\mathrm{CO}_{2}$. This method was chosen as the level of GABA has been shown to increase rapidly after death (Lovell et al., 1963). Alderman and Shellenberger (1974) have suggested that for regional

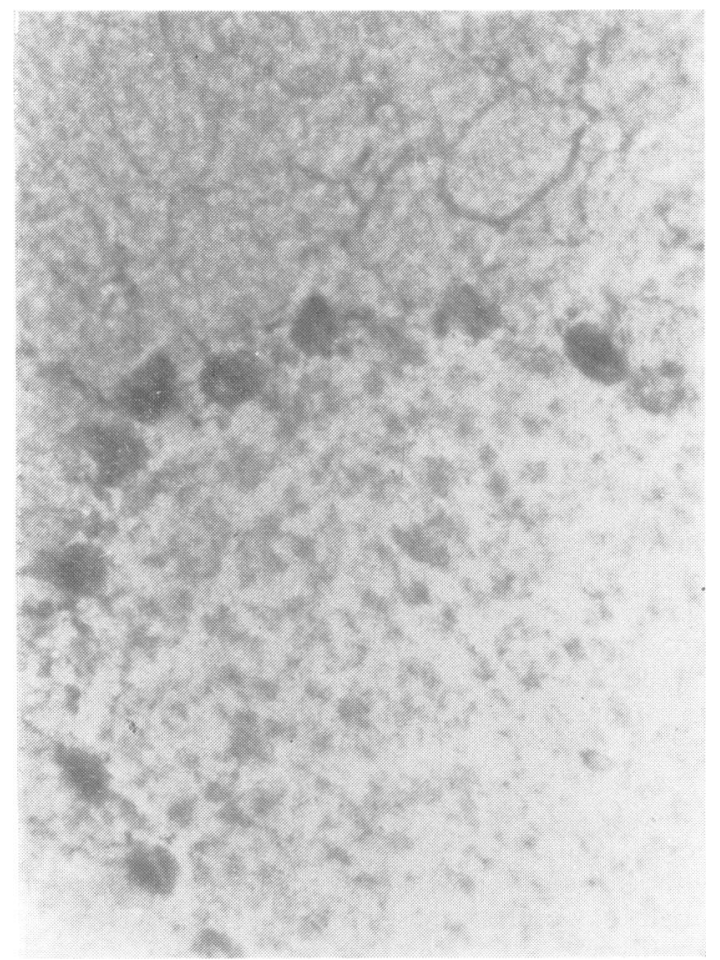

Fig. 1 Intensely stained $G A B A$ reaction within Purkinje cells lying between molecular layer above and granule cell layer below in control animal. $\times 25$.

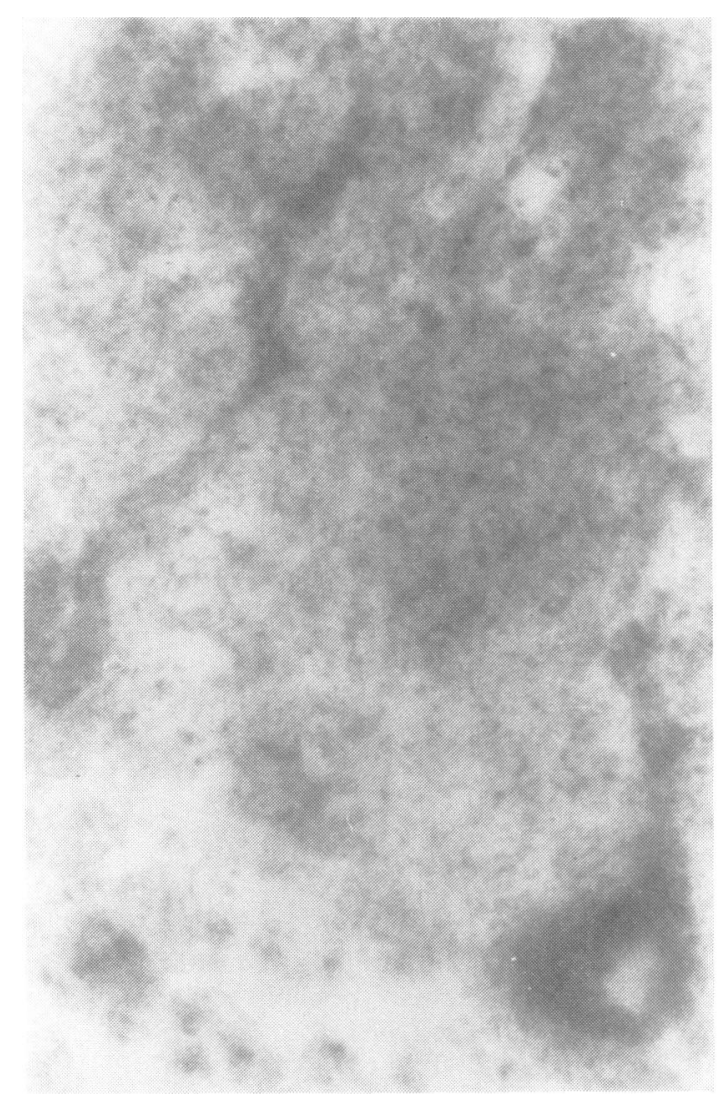

Fig. 2 Intense $G A B A$ reaction in Purkinje cells and processes in control animal. $\times 100$.

studies of GABA, removal of the brain within 30 seconds with subsequent freezing is the best approach. The frozen tissues were placed in a 'Slee' cryostat with a chamber temperature of $-20^{\circ} \mathrm{C}$ and cut at $15 \mu \mathrm{m}$. The sections were mounted on cover slips at room temperature and stored in a desiccator at $-20^{\circ} \mathrm{C}$ for three hours, then incubated using a modification of the method of Van Gelder (1965) with $10 \mathrm{mg}$ instead of $25 \mathrm{mg} \alpha$-oxoglutarate. Sections were examined under the microscope and values given for the staining intensity of the Purkinje cells on a four point scale: ++++ intense, +++ strong, ++ moderate, + weak (Robinson and Wells, 1973)(Figs. 1-4). These observations were made by the same observer unaware of the control or test status of the animal. An early attempt to produce standardisation by the use of colour scales was abandoned in favour of direct and immediate microscopic assessments because of their greater reliability. Succinate dehydrogenase was demonstrated by the Pearse modification (Pearse, 


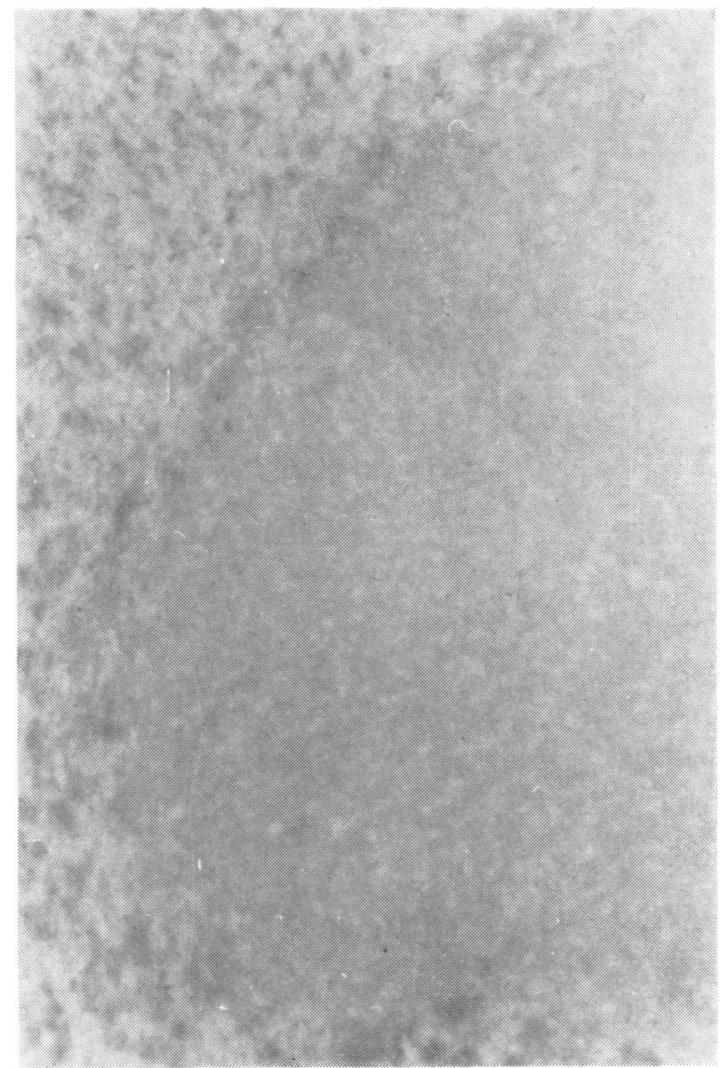

Fig. 3 Weakly stained GABA reaction in Purkinje cells in test animal. $\times 25$.

1972). GABA and $\alpha$-oxoglutarate were obtained from Sigma London and sodium succinate from BDH Chemicals Ltd. The diphenylhydantoin was obtained from a commercial preparation (Parke Davis).

\section{Results}

No obvious toxic disorder appeared from the administration of the low doses of DPH in the first group. In the second group with acute experiments, rats with high doses were soon very sick and often ataxic.

The effect of DPH was to reduce the GABA content in Purkinje cells by a statistically significant amount $(\mathrm{P}<0.001)$ when given in doses of more than $12.5 \mathrm{mg} / \mathrm{kg}$ body weight (Tables 1 and 2). A positive correlation between dose and GABA loss appeared to exist up to the critical level of $75 \mathrm{mg} / \mathrm{kg}$ (rank correlation coefficient $+\mathbf{0 . 8 3}$ ) when the relationship became less marked.

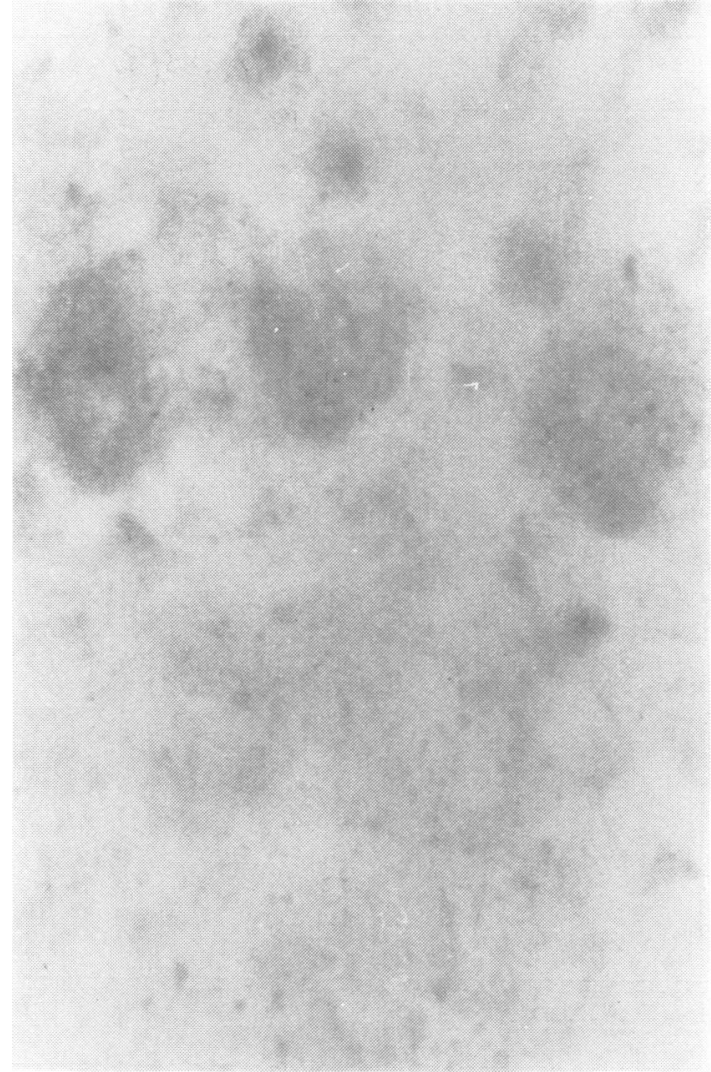

Fig. 4 Weakly stained GABA reaction in Purkinje cells in test animal. $\times 100$.

No change was noted in succinate at any dosage level.

\section{Discussion}

The investigation has shown that DPH produces a decrease of GABA in Purkinje cells, and confirms the findings of Karkos (1975) that there is no effect on succinic dehydrogenase activity in Purkinje cells. As he pointed out, however, this does not exclude the effect of the drug at other stages of the Krebs cycle, and our findings suggest that this is at the level of the gamma aminobutyric acid portion of the cycle. If DPH acted as an accelerator of GABA metabolism, high levels of succinate could be expected, but this was not the case. It is also possible that the reduction of GABA could be due to reduced activity in the synthesising enzyme glutamate decarboxylase (GAD). Studies of GAD are necessary in order to elucidate the action of DPH since it is possible that decrease in 
Table 1 Influence of DPH on Purkinje cell GABA

\begin{tabular}{|c|c|c|c|c|c|c|}
\hline Animal & Control & $\begin{array}{l}1.25 \mathrm{mg} / \mathrm{kg} \\
\text { body weight }\end{array}$ & Control & $\begin{array}{l}12.5 \mathrm{mg} / \mathrm{kg} \\
\text { body weight }\end{array}$ & Control & $\begin{array}{l}50 \mathrm{mg} / \mathrm{kg} \\
\text { body weight }\end{array}$ \\
\hline $\begin{array}{r}1 \\
2 \\
3 \\
4 \\
5 \\
6 \\
7 \\
8 \\
9 \\
10\end{array}$ & $\begin{array}{l}++++ \\
++ \\
++++ \\
+++ \\
++ \\
++ \\
+ \\
++++ \\
+ \\
++++\end{array}$ & $\begin{array}{l}+ \\
+++ \\
++ \\
+ \\
++ \\
++++ \\
+ \\
++ \\
++\end{array}$ & $\begin{array}{l}+++t \\
+++t \\
+++ \\
++++ \\
++++ \\
++++ \\
++++ \\
++++\end{array}$ & $\begin{array}{l}+++ \\
++ \\
++ \\
+++ \\
++ \\
++ \\
++ \\
+\end{array}$ & $\begin{array}{l}++ \\
+++ \\
++t+ \\
++t\end{array}$ & $\begin{array}{l}+ \\
++ \\
+ \\
++ \\
++ \\
++ \\
+ \\
+\end{array}$ \\
\hline Mean & 2.70 & 2.00 & 3.88 & 2.13 & 3.00 & 1.50 \\
\hline SD & 1.25 & 1.00 & 0.35 & 0.64 & 0.82 & 0.53 \\
\hline$t$-test & & $P<0.1$ & & $P<0.001$ & & $P<0.001$ \\
\hline
\end{tabular}

Table 2 Influence of DPH on Purkinje cell GABA

\begin{tabular}{|c|c|c|c|c|}
\hline Animal & Control & $\begin{array}{l}75 \mathrm{mg} / \mathrm{kg} \\
\text { body weight }\end{array}$ & $\begin{array}{l}87.5 \mathrm{mg} / \mathrm{kg} \\
\text { body weight }\end{array}$ & $\begin{array}{l}100 \mathrm{mg} / \mathrm{kg} \\
\text { body weight }\end{array}$ \\
\hline $\begin{array}{r}1 \\
2 \\
3 \\
4 \\
5 \\
6 \\
7 \\
8 \\
9 \\
10\end{array}$ & $\begin{array}{l}+++ \\
+++ \\
++++ \\
++++ \\
+ \\
++ \\
++++ \\
++ \\
+++ \\
++++\end{array}$ & $\begin{array}{l}++ \\
+ \\
+ \\
+ \\
+\end{array}$ & $\begin{array}{l}+ \\
+++ \\
++ \\
++ \\
++\end{array}$ & $\begin{array}{l}+ \\
+ \\
++ \\
++ \\
++\end{array}$ \\
\hline Mean & 3.00 & 1.20 & 2.00 & 1.60 \\
\hline SD & 1.05 & 0.45 & 0.71 & 0.55 \\
\hline$t$-test & & $P<0.001$ & $P<0.05$ & $P<0.01$ \\
\hline
\end{tabular}

glutamic acid production and increase of GABA by DPH inhibits synaptic transmission and prevents the spread of discharge in convulsions, thus accounting for the anticonvulsant effect of the diphenylhydantoin (Woodbury, 1969). Toxic doses of DPH, therefore, might produce increase of GAD as well as decrease of GABA. On the other hand, hydantoins, which are structural analogues of GABA, could compete with it (Meldrum, 1975) in high doses and thus result in decreased levels of GABA. It has been suggested that anticonvulsants exert their effect by activation of Purkinje cells which inhibit the epileptic activity in the cerebral-cerebellar pathways (Halpern and Julien, 1972; Julien, 1974; Bantli et al., 1976). Our findings confirm the important relationship between the Purkinje cell and DPH, and suggest that this is the site of action of DPH and of the loss of epileptic control in overdosage.

This work, which was partly supported by the MacRobert Epilepsy Research Grant, was carried out in the laboratories of the Teaching and Research Centre,
Western General Hospital, Edinburgh. We are grateful to Mr M. Neil, Group Chief Pharmacist at the Western General Hospital, for preparing the injection solutions, to Mr Jeremy Hitchcock for help in the statistical analysis, and to Mrs Edna MacDonald for correcting and typing the manuscript.

\section{References}

Alderman, J. L., and Shellenberger, M. K. (1974). Gamma aminobutyric acid (GABA) in the rat brain: reevaluation of sampling procedures and the post mortem increase. Journal of Neurochemistry, 22, 937-940.

Bantli, H., Bloedel, J. R., and Tolbert, D. (1976). Activation of neurones in the cerebellar nuclei and ascending reticular formation by stimulation of the cerebellar surface. Journal of Neurosurgery, 45, 539-554.

Fahn, S., and Côté, L. J. (1968). Regional distribution of gamma aminobutyric acid (GABA) in brain of the Rhesus monkey. Journal of Neurochemistry, 15, 209-213.

Glaser, G. H. (1972). Diphenylhydantoin toxicity. In Anti-epileptic Drugs, pp. 219-226. Edited by D. M. Woodbury, J. K. Penry, and R. P. Schmidt. Raven Press: New York.

Gordon, N. (1969). Use of diphenylhydantoin in epilepsy treatment. Developmental Medicine and Child Neuro$\log y, 11,111-112$.

Halpern, L. M., and Julien, R. M. (1972). Augmentation of cerebellar Purkinje cell discharge rate after diphenylhydantoin. Epilepsia, 13, 377-385.

Julien, R. M. (1974). Experimental epilepsy: cerebrocerebellar interactions and antiepileptic drugs. In The Cerebellum, Epilepsy and Behavior, pp. 97-118. Edited by I. S. Cooper, M. Riklan, and R. S. Snider. Plenum Press: New York.

Karkos, J. (1975). Effect of phenytoin on succinic dehydrogenase activity in rat cerebellum. Polish Medical Sciences and History Bulletin, 1, 45-48.

Kutt, H., Winters, W., Kokenge, R., and McDowell, F. (1964). Diphenylhydantoin metabolism, blood levels 
and toxicity. Archives of Neurology (Chicago), 11, 642-648.

Levy, L. L., and Fenichel, G. M. (1965). Diphenylhydantoin activated seizures. Neurology (Minneapolis), 15, $716-722$.

Logan, W. J., and Freeman, J. M. (1969). Pseudodegenerative disease due to diphenylhydantoin intoxication. Archives of Neurology (Chicago), 21, 631-637.

Lovell, R. A., Elliott, S. J., and Elliott, K. A. C. (1963). The GABA and Factor 1 content of brain. Journal of Neurochemistry, 10, 479-488.

Meldrum, B. S. (1975). Epilepsy and gamma aminobutyric acid mediated inhibition. International Review of Neurobiology, 17, 1-36.

Noach, E. L., Woodbury, D. M., and Goodman, L. S. (1958). Studies on the absorption, distribution, fate and excretion of 4-C $\mathrm{C}^{14}$ labelled diphenylhydantoin. Journal of Pharmacology and Experimental Therapeutics, 122, 301-314.

Pearse, A. G. E. (1972). Histochemistry, Theoretical and Applied. Vol. 2. Churchill Livingstone: Edinburgh and London.
Robinson, N., and Wells, F. (1973). Distribution and localization of sites of gamma aminobutyric acid metabolism in the adult rat brain. Journal of Anatomy (London), 114, 365-378.

Saad, S. F., El Masry, A. M., and Scott, P. M. (1972). Influence of certain anticonvulsants on the concentration of gamma aminobutyric acid in the cerebral hemisphere of mice. European Journal of Pharmacology, 17, 386-392.

Sawaya, M. C. B., Horton, R. W., and Meldrum, B. S. (1975). Effects of anticonvulsant drugs on the cerebral enzymes metabolising GABA. Epilepsia, 16, 649-655.

Van Gelder, N. M. (1965). The histochemical demonstration of gamma aminobutyric acid metabolism by reduction of a tetrazolium salt. Journal of Neurochemistry, 12, 231-237.

Woodbury, D. M. (1969). Mechanism of action of anticonvulsants. In Basic Mechanisms of the Epilepsies, pp. 647-680. Edited by H. H. Jasper, A. A. Ward, and A. Pope. Little, Brown \& Co: Waltham, Massachusetts. 